\title{
Intragenic Sequences Are Required for Cell Type-specific and Injury-induced Expression of the Rat Peripherin Gene
}

\author{
Teri Belecky-Adams,' David C. Wight, ${ }^{2}$ John J. Kopchick, ${ }^{2}$ and Linda M. Parysek' \\ 'Department of Anatomy and Cell Biology, University of Cincinnati College of Medicine, Cincinnati, Ohio 45267-0521 and \\ the ${ }^{2}$ Department of Biological Sciences and Edison Animal Biotechnology Center, Ohio University, Athens, Ohio 45701
}

\begin{abstract}
Peripherin is a $57 \mathrm{kDa}$ type III intermediate-filament protein that is thought to play a role in axonogenesis both during development and following nerve injury (Oblinger et al., 1989; Escurat et al., 1990; Gorham et al., 1990; Troy et al., 1990b). We have used transgenic mouse technology to define peripherin gene sequences that are necessary for cell typespecific expression and for the increase in peripherin that occurs in response to axonal injury. Correct temporal and nervous system-specific expression resulted when 5.8 kilobases of peripherin $5^{\prime}$ flanking sequence were linked to a reporter gene, but precise cell type-specific expression was achieved only when intragenic sequences were included. When intragenic sequences were present, peripherin transgenes were expressed in dorsal root ganglion neurons and spinal cord motor neurons and were upregulated in these cells following nerve injury.

[Key words: peripherin, nerve injury, transgenic mice, neuron-specific expression, intermediate filament, gene regulation]
\end{abstract}

Regeneration of PNS neurons is key to reinnervation of damaged tissues after traumatic injury. The regeneration response of the neuron involves programmed gene expression triggered by factors in the local environment, such as Schwann cells and Schwann cell-specific and target-derived growth regulators (Watson, 1974; Grafstein, 1975; Varon, 1977; Heumann et al., 1987a; Skene, 1989). A number of genes, including those that encode GAP43 (Basi et al., 1987), NCAM and NgCAM (Daniloff et al., 1986), the NGF receptor (Heumann et al., 1987b; Ernfors et al., 1989), and major cytoskeletal elements of the axon (Goldstein et al., 1988; Hoffman and Cleveland, 1988; Oblinger et al., 1989; Troy et al., 1990b; Wong and Oblinger, 1990), show upregulated expression patterns that indicate their involvement in the regrowth of the injured axon. The mechanism of this response is not known. These genes provide targets, however, for the study of an important component of the response, the injury-responsive cis-acting elements in the genome.

\footnotetext{
Received Feb. 15, 1993; accepted June 3, 1993.

We thank Dr. Monica Oblinger for her invaluable help with nerve transections, Dr. Robert Brackenbury for helpful comments on the manuscript, and Thomas DiCarlo and Catherine Ley for technical assistance. This work was supported by grants from the NICHD and the Boothroyd Foundation, and a March of Dimes Basil O'Connor Starter Scholar Award to L.M.P. J.J.K. was supported in part by the State of Ohio Eminent Scholar Program, which includes a grant by Milton and Lawrence Gall. T.B.-A. was supported in part by a fellowship from the Albert J. Ryan Foundation.

Correspondence should be addressed to Linda M. Parysek, Department of Anatomy and Cell Biology, University of Cincinnati College of Medicine, 231 Bethesda Avenue, Cincinnati, $\mathrm{OH}$ 45267-0521.

Copyright (C) 1993 Society for Neuroscience $0270-6474 / 93 / 135056-10 \$ 05.00 / 0$
}

We have focused our analyses on one cytoskeletal gene, that encoding the intermediate-filament (IF) protein peripherin, that is significantly upregulated in response to nerve injury.

Peripherin was first described in neuroblastoma cell lines (Portier et al., 1982), and was subsequently identified in a subset of neurons in the PNS, as well as in a few groups of neurons in the CNS (Portier et al., 1984; Parysek and Goldman, 1987, 1988; Leonard et al., 1987, 1988; Parysck ct al., 1988; Brody et al., 1989), where it is a subunit of axonal IF (Parysek et al., 1991). Peripherin shows a limited distribution within the nervous system, in contrast to the widespread distribution of the neural IF protein triplet (NF-L, NF-M, and NF-H), but the study of peripherin distribution patterns has provided little insight into peripherin gene function.

Studies on development and on the nerve injury response, however, have suggested a role for peripherin in axonogenesis. In the mouse, peripherin expression is initially apparent in the embryo at a time when neurons differentiate and extend axonal processes (Sharpe et al., 1989; Escurat et al., 1990; Gorham et al., 1990; Troy et al., 1990a). Similarly, in a response that appears to recapitulate development, peripherin expression increases during the growth of new daughter axons after peripheral nerve injury (Oblinger et al., 1989; Wong and Oblinger, 1990). The large-sized cells of the dorsal root ganglion (DRG), which generally express significant amounts of peripherin only during development (Escurat et al., 1990; Gorham et al., 1990; Troy et al., 1990a), show a twofold increase in peripherin mRNA within $24 \mathrm{hr}$ after nerve crush in adult animals (Wong and Oblinger, 1990). Peripherin is upregulated not only in the largesized neurons of the DRG, but also in the motor neurons of the anterior horn of the spinal cord (Troy et al., 1990b). Thus, peripherin is implicated in the development of axons and their regrowth after injury.

Transgenic animals are uniquely suited to define regions of the peripherin gene necessary for developmental-specific expression and for upregulation following axonal injury. In this article, we report analyses of the expression of two peripherin transgenes in mice. One gene included 5.8 kilobases $(\mathrm{kb})$ of rat peripherin $5^{\prime}$ flanking sequences driving a reporter gene, the bacterial lac $Z$ gene. The second gene included the same length of $5^{\prime}$ flanking sequences driving the full-length peripherin gene tagged with a segment of the human c-myc gene. We found that the $5^{\prime}$ flanking region alone was sufficient to direct nervous system-specific expression of the heterologous reporter gene. Complete tissue-specific expression, however, was achieved only when the entire peripherin gene, including introns, was contained in the construct. Analyses of these transgenic mice after nerve crush revealed that only the construct containing the in- 
PERIPH/LACZ

Peripherin $5^{\prime}$ Flanking Sequence

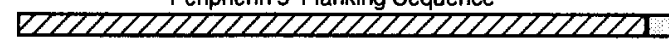

LacZ Gene SV4O PA $\mathrm{r} 3$

\section{PERIPH/PERIPH-MYC}

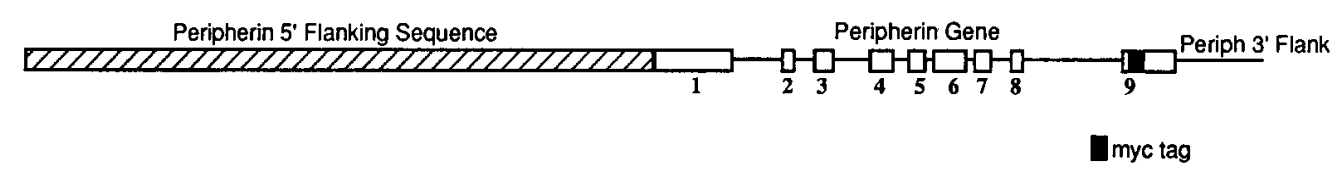

Figure 1. Graphic representation of linear transgenes. The hatched boxes represent $5.8 \mathrm{~kb}$ of rat peripherin gene 5 ' flanking sequence, numbered blank boxes represent rat peripherin gene exons, and the solid lines represent the intervening sequences. A human c-myc tag (solid box) was placed in-frame in the $3^{\prime}$ portion of exon 9 to facilitate localization of the periph/periph-myc transgene product. tragenic sequences showed an injury-induced increase in peripherin expression.

\section{Materials and Methods}

Plasmid construction. Rat peripherin gene sequences used for the transgene constructions were isolated as described previously (Parysek et al., 1991). The first construct, $5^{\prime}$ periph/lacZ, contained $5.8 \mathrm{~kb}$ of the $5^{\prime}$ flanking rat peripherin sequences linked at the peripherin gene cap site (Thompson and Ziff, 1989), at a PstI site, to the lacZ gene derived from pSDKlacZ pA (S. Darling, University College, London) (Logan et al., 1993). The lac $Z$ gene contained a Kozak consensus sequence for eukaryotic translation initiation (Kozak, 1987) and an SV40 polyadenylation sequence. The second construct included $5.8 \mathrm{~kb}$ of 5 ' flanking rat peripherin gene sequences, the rat peripherin gene, and 600 base pairs (bp) of 3' flanking rat peripherin gene sequence. In this $9.8 \mathrm{~kb}$ genomic segment, a human c-myc sequence was inserted into exon 9 at the TthlllI site such that the terminal 18 amino acids encoding peripherin were replaced with amino acids encoding human c-myc. The $3^{\prime}$ end of the endogenous peripherin amino acid sequence, KVVTESQKEQHSELDKSSIHSY, was replaced with KVVTSLGDLTMEQKLISEEDLN in the peripherin-myc protein. The rat peripherin gene $3^{\prime}$ untranslated sequence and natural polyadenylation signal were retained (periph/periph-myc, Fig. 1).

Transgenic mice. Transgenic mice were generated according to standard protocols (Chen et al., 1991) by injection of linear transgene DNA into the male pronucleus of one-cell mouse embryos obtained from F1 hybrid animals of SJL $\times$ C57BL/6 matings. Mice bearing the transgenes were identified by Southern analyses of DNA isolated from tails (Sambrook et al., 1989) or by polymerase chain reaction (PCR) (Hanley and Merlie, 1991). Founder animals and their offspring were mated to F1 SJL $\times$ C57BL/6 hybrid mice (Jackson Labs, Bar Harbor, ME) to maintain a hemizygous line.

Immunohistochemical analyses. Selected tissues were dissected from mice killed at 4 weeks of age and then embedded in $7.0 \%$ gelatin and frozen in a dry ice/ethanol bath. The tissues were stored at $-70^{\circ} \mathrm{C}$. Cryostat sections $(6 \mu \mathrm{m})$ either were labeled by indirect immunofluorescence as described in Foley et al. (1991) or by indirect immunostaining using an $\mathrm{ABC}$ Vectastain kit (Vector Labs, Inc.), or, in the case of tissues analyzed for the expression of the lac $Z$ transgene, were subjected to a $\beta$-galactosidase ( $\beta$-gal) colorimetric assay using X-gal. $\beta$-gal-stained sections were counterstained with neutral red. Antibodies used for immunolabeling included a rabbit peripherin antiscrum (Brody et al., 1989), a monoclonal antibody to human c-myc (Evan et al., 1985), and a monoclonal antibody to $\beta$-gal (Promega). Reaction products were visualized in a Zeiss Axiophot microscope, and pictures were taken with T-Max 400 or T-Max 100 film and developed in T-Max developer.

Embryonic studies. To obtain embryos, male transgenic mice were mated with wild-type SJL $\times$ C57BL/6 female mice under standard breeding conditions (Hogan et al., 1986). The day of appearance of the vaginal plug was designated $\mathrm{E} 0$. Embryos were removed from anesthetized, decapitated mothers at E6, E8, E9, E10, E12, or E1 5. E6 embryos were not dissected free from the uterus. All embryos were soaked in $30 \%$ sucrose in $0.1 \mathrm{M}$ phosphate buffer at $4^{\circ} \mathrm{C}\left(6 \mathrm{mM} \mathrm{KH}_{2} \mathrm{PO}_{4}, 200 \mathrm{mM}\right.$ $\mathrm{Na}_{2} \mathrm{HPO}_{4}, \mathrm{pH} 7.3$ ) for $2 \mathrm{hr}$, and then rinsed in $0.1 \mathrm{~m}$ phosphate buffer. Tails were dissected from of the embryos and used to identify mice positive for the transgene by PCR. Embryos were cmbedded, scetioned, and analyzed as other tissues described above. Some whole embryos (E8, E9, E10, E12) containing the lacZ transgene were subjected to whole embryo staining for $\beta$-gal (Kress et al., 1990).
SDS-PAGE and immunoblots. Whole sciatic nerves taken from adult mice were solubilized in either Laemmli sample buffer or $8.0 \mathrm{M}$ urea in $100 \mathrm{~mm}$ Tris, pH 7.5, in direct proportion to the wet weight of the nerve. Control and transgenic samples containing equivalent amounts of protein were run on SDS-PAGE gels, transferred to Immobilon P (Millipore), and immunoblotted according to standard methods (Towbin et al., 1979).

Nerve transections. Adult mice were anesthetized by intramuscular injection of $0.3 \mathrm{gm} / \mathrm{kg}$ Avertin $(12.5 \mathrm{mg} / \mathrm{ml} \mathrm{2,2,2-tribromoethanol} \mathrm{and}$ $8 \mu \mathrm{l} / \mathrm{ml} 2$-methanol-2-butanol in water). PNS neurons were injured by crushing the sciatic nerve unilaterally at the midthigh level using sharpened \#5 Dumont forceps. The nerve was crushed twice in the same area for approximately $30 \mathrm{sec}$ each. Sham-operated controls were anesthetized, and the sciatic nerve was located but not crushed. Axotomized and sham-operated mice were allowed to recover from the nerve crush for $10 \mathrm{~d}$. The mice then were killed, and the spinal cord and L4 and L5 DRGs from both sides were removed. The tissues were placed in $7 \%$ gelatin, frozen, and analyzed as described in Immunohistochemical analyses, above.

\section{Results}

Segments of the rat peripherin gene were tested for their contribution to cell type-specific and developmental-specific expression of rat peripherin and its upregulation following injury to peripheral nerves by comparing the expression of two peripherin gene constructs in transgenic mice. One construct included $5.8 \mathrm{~kb}$ of rat $5^{\prime}$ peripherin flanking sequence linked to a lac $Z$ reporter gene (periph/lacZ, Fig. 1) and the other construct contained $5.8 \mathrm{~kb}$ of the rat $5^{\prime}$ peripherin flanking sequences driving the rat peripherin gene tagged by insertion of human $c-m y c$ gene sequences into the $3^{\prime}$ end of the peripherin gene (periph/periph-myc, Fig. 1). The number of copies of the transgene present in the genome of various lines ranged from 1 to 250 as determined by Southern analyses (data not shown). Expression of the transgenes was characterized by determining the distribution of $\beta$-gal or peripherin- $m y c$ proteins in tissue obtained from the $\mathrm{F} 1$ generation and subsequent generations of hemizygous transgenic animals.

\section{Adult periph/lacZ expression}

Twelve founders containing the periph/lac $Z$ transgene were generated. Seven of the 12 transgenic lines gave rise to hemizygotes that expressed $\beta$-gal in adult tissue. Cell specificity of lac $\angle$ transgene expression was examined by immunofluorescence, $\beta$-gal staining of sections, or whole-mount $\beta$-gal staining of brainstem, spinal cord, DRG, small intestine, and liver. These tissues were chosen because they display characteristic patterns of peripherin protein expression and represent CNS (brainstem and spinal cord), PNS (DRG), autonomic nervous system (thoracic spinal cord, small intestine), and control, non-neuronal tissue (small intestine and liver).

The distribution patterns defined by $\beta$-gal staining in adult 

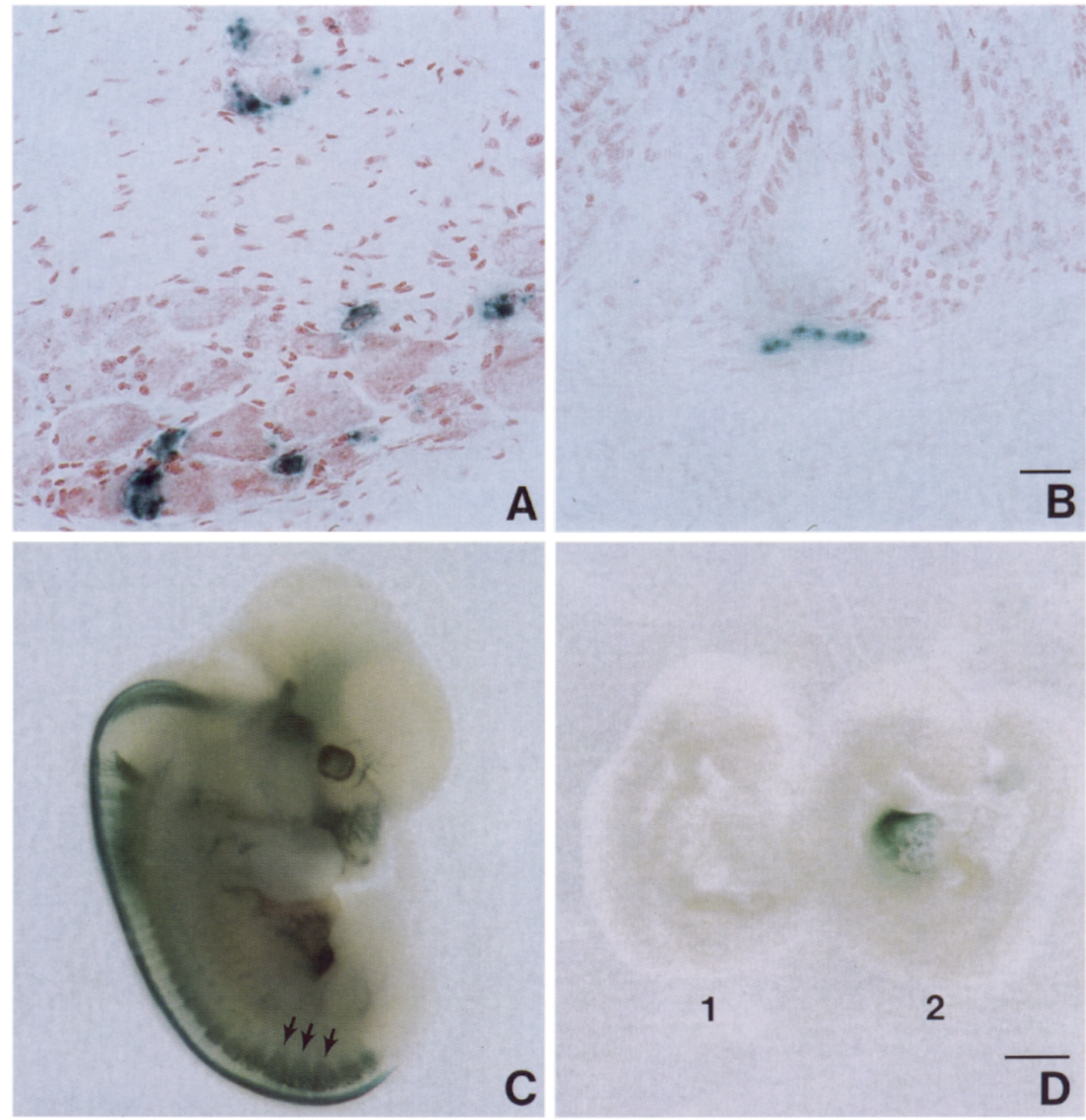

Figure 2. Periph/lac $Z$ and the endogenous peripherin gene are coexpressed in adult and embryonic tissues, but the distribution of $\beta$-gal is not as extensive as peripherin. $A$ and $B$, Sections of the DRG $(A)$ and small intestine $(B)$ of adult periph/lac $Z$ mice showed that only a subset of smallsized DRG cells $(A)$ or of enteric neurons $(B)$ stained for $\beta$-gal. The $5^{\prime}$ flanking sequences of the peripherin gene were sufficient to direct heterologous gene expression to cells that typically contain peripherin, but did not direct full cell type-specific expression. $C$ and $D$, Whole embryo staining of periph/lacZ mice showed the distribution of $\beta$-gal in the DRGs (arrows) and peripheral nerves at E12 $(C)$ and in the rostral cardiac region at E9 (embryo 2 in $D$ ). Embryo $1(D)$ illustrates the lack of endogenous $\beta$-gal staining in a nontransgenic littermate. Scale bars: $A$ and $B, 20 \mu \mathrm{m} ; C$ and $D, 1 \mathrm{~mm}$.

mouse tissues indicated that $\beta$-gal expression, like that of endogenous peripherin, was enriched in the PNS. Non-neuronal cells in tissues like liver and small intestine did not express the transgene. Not all cells known to express peripherin, however, were $\beta$-gal positive. For example, $\beta$-gal expression was restricted to a subset of sensory cells (only some of the small-sized cells) in the DRG (Fig. $2 A$ ) that express peripherin. Further, only one line expressed $\beta$-gal in the autonomic nervous system, in the enteric neurons of the wall of the small intestine (Fig. $2 B$ ); none contained $\beta$-gal in anterior horn motor neurons. Thus, $\beta$-gal expression was detected in cells that normally contain peripherin, but transgene expression was not as extensive as that of endogenous peripherin.

Four lines expressed $\beta$-gal ectopically, that is, in cells that normally do not express peripherin. In most instances, the ectopic $\beta$-gal appeared to be associated with cells that had large, euchromatic nuclei typical of neurons and was distributed in a manner that was characteristic of neurons rather than glial elements. The ectopic expression was not localized to defined groups of cells; rather, it appeared to be scattered in the spinal 
cord and brainstem. Therefore, periph/lac $Z$ was expressed in a nervous system-specific and probably neuron-specific manner, though not always cell type-specific for peripherin-containing neurons.

These general trends in the pattern of lac $Z$ transgene expression were overlain by another characteristic, that of variability among the mouse lines. Not only did the number and location of ectopically expressing $\beta$-gal cells vary, but the percentage of peripherin-positive cells that also expressed $\beta$-gal varied considerably. While $5.8 \mathrm{~kb}$ of rat peripherin $5^{\prime}$ flanking sequences was sufficient to restrict expression of the lac $Z$ gene to the nervous system, this expression was highly variable among lines.

\section{Embryonic periph/lacZ expression}

To determine whether sequences contained within the periph/ lac $Z$ construct were sufficient to direct appropriate expression in early development, whole embryo $\beta$-gal staining was performed on periph/lac $Z$ embryonic hemizygotes. The embryos chosen for these analyses were offspring of a line of mice that showed adult $\beta$-gal expression that was most like peripherin.

In the nervous system, specifically in DRGs, $\beta$-gal expression was noted initially on E10, as has been reported for peripherin (Troy et al., 1990a). $\beta$-gal distribution was much more extensive at E12 in the PNS, especially in DRGs and peripheral nerves (Fig. $2 C$ ), in a pattern typical of peripherin at this age. The extent of $\beta$-gal in the PNS was examined further in sections of periph/lac $Z$ embryos. These analyses showed that, whereas endogenous peripherin was found in all the neurons of the DRG at this stage of development, $\beta$-gal already was confined to a subpopulation of neurons in the DRG (data not shown). This indicated that sequences needed for expression in all the DRG neurons during development were not included in the periph/ lac $Z$ construct. Only one line of animals showed expression in the presumptive anterior horn motor neurons during development. In terms of the developmental onset of peripherin expression, however, embryonic $\beta$-gal expression was identical to that of endogenous peripherin.

The most striking staining at early stages was seen in the heart region of the embryo (E9; Fig. 2D). The staining appeared as early as E8 and was restricted to cells and fibers in the rostral region of the heart. This staining was unexpected because peripherin expression in the embryonic or adult heart has not been noted previously. To determine whether endogenous peripherin also was expressed in embryonic heart, nontransgenic animals were labeled with peripherin antibody and found to contain peripherin in the same region of the heart where $\beta$-gal was expressed (see Fig. $5 B$ ). E12 mice still expressed $\beta$-gal in the heart region, although the label was diminished as compared to their E10 counterparts, when $\beta$-gal expression in the rostral cardiac region appeared to be greatest. Embryonic littermates negative for the transgene showed no $\beta$-gal expression at any age except for endogenous $\beta$-gal staining in the small intestine.

\section{Periph/periph-myc adult expression}

To determine the contribution of intragenic sequences to the regulation of peripherin expression, a tagged peripherin gene containing the same peripherin $5^{\prime}$ flanking sequences as those contained in the $l a c Z$ construct (periph/periph-myc) was introduced into the mouse germline. F1 progeny derived from founders containing the periph/periph-myc transgene were analyzed by double-label immunofluorescence with myc antibody, which labeled protein expressed from the transgene, and peripherin antiserum, which detected total peripherin expression. In addition, these expression patterns were compared to those of nontransgenic littermates. Several tissues were examined, including brainstem, spinal cord, DRG, small intestine, and liver. Of the seven lines produced, five lines expressed peripherin$m y c$ protein and two lines did not express the transgene.

In contrast to the large variation in expression patterns among the lines of periph/lac $Z$ mice, the five periph/periph-myc lines showed highly similar transgene expression in which the distribution of peripherin-myc protein was nearly identical to that of the endogenous peripherin protein. In sensory neurons, such as those in the DRG and brainstem, three of the five lines showed complete overlap of transgene and endogenous peripherin gene expression (Fig. $3 A, B$ ). In the other two lines, a subset of peripherin-containing DRG neurons expressed the transgene. Every line also contained excellent overlap of transgene and endogenous peripherin expression in autonomic nervous system enteric neurons (Fig. $3 C, D$ ), in brainstem motor neurons and in cranial ganglia. In all these areas, only a few peripherin-containing cells did not express the transgene.

In motor neurons of the anterior horn of the spinal cord, one line showed nearly perfect correlation of transgene and endogcnous peripherin gene expression $(94.8 \% \pm 1.06 \mathrm{SD})$. The neurons that did not show coexpression were only weakly immunoreactive for peripherin, suggesting that peripherin-myc may be expressed in these cells, but that the amount of peripherin$m y c$ expressed is at the lower limit of immunodetectability. Consistent differences between endogenous peripherin gene and transgene expression were seen in spinal cord motor neurons in four of the five lines that expressed the transgene (Fig. $3 E, F$ ). The subset of peripherin-positive motor neurons, however, were not distinguished by size, anatomical location of the neuron, or properties of the muscles innervated by those neurons (data not shown). Thus, in at least one line, the transgene was fully expressed in lumbar motor neurons that normally express peripherin.

To determine the molecular size and relative abundance of the peripherin-myc protein, samples of sciatic nerve were analyzed on immunoblots. Analysis of whole sciatic nerve protein from a transgenic mouse indicated that the protein product of the periph/periph-myc transgene is, as expected, the same molecular weight as endogenous peripherin (Fig. 4). A negative littermate showed no reactivity with the $m y c$ antibody (Fig. 4, lane 4). The relative amounts of peripherin and peripherin-myc in urea-solubilized samples were determined by comparing the total peripherin protein immunoreactivity in sciatic nerve samples from transgenic animals, which express endogenous peripherin and peripherin-myc, and nontransgenic littermates, which express only endogenous peripherin. Densitometric measurements indicated that transgenic mouse sciatic nerve extracts contained approximately twice as much peripherin protein as the negative control (data not shown), suggesting that there are approximately equal levels of peripherin-myc protein and endogenous peripherin protein in these animals.

In summary, for the most part, expression of the periph/ periph-myc transgene was identical to that of endogenous peripherin. In addition, as compared to periph/lac $Z$ transgene expression, (1) there was no ectopic expression of peripherin-myc, (2) there was very little variability among lines of mice examined, and (3) within all the populations of peripherin-expressing cells, the periph/periph-myc transgene was expressed in a greater proportion of cclls. 

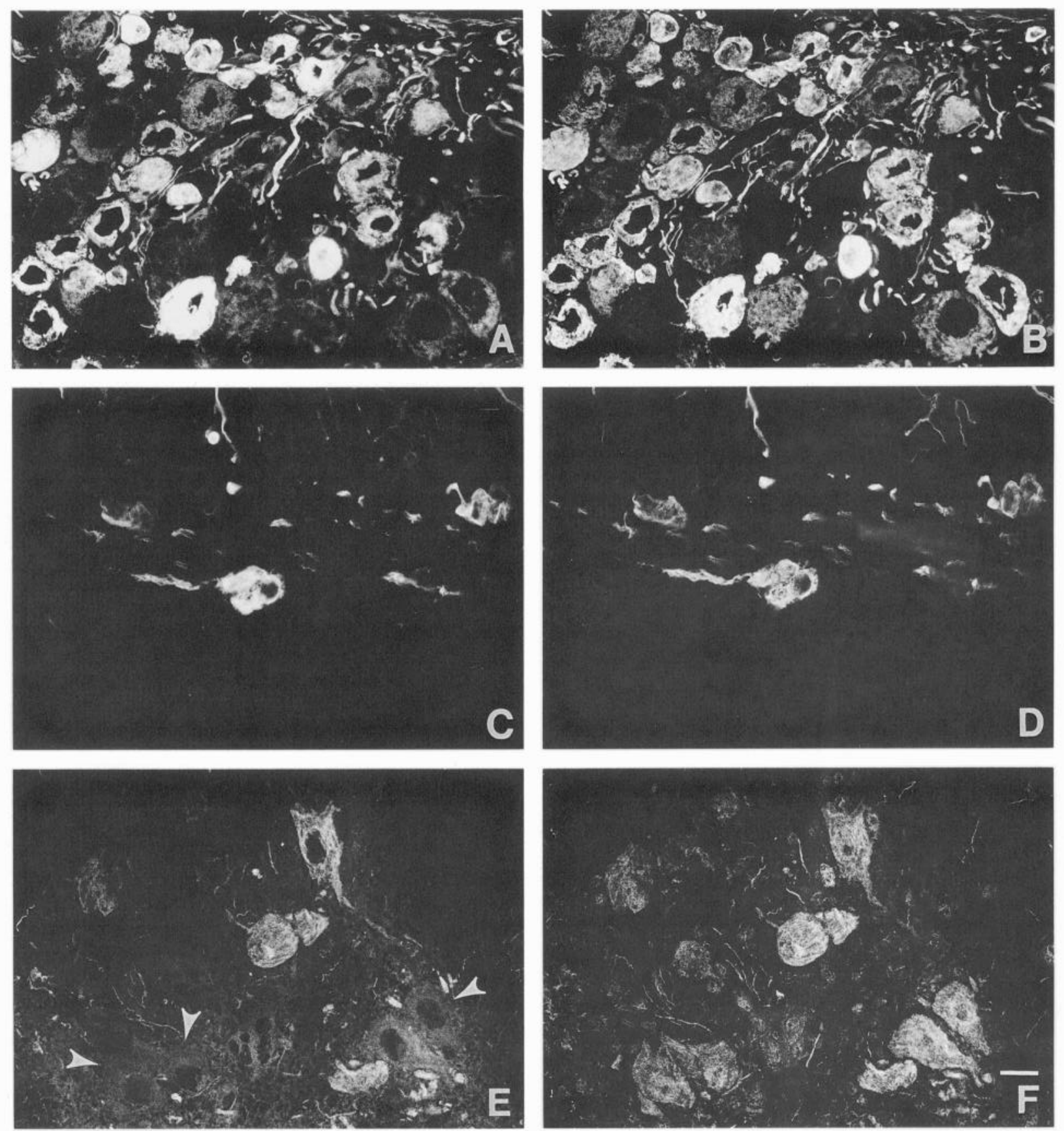

Figure 3. Expression of the periph/periph-myc fusion protein in transgenic mice closely overlaps the expression of endogenous peripherin. Sections of the DRG $(A, B)$ and small intestine $(C, D)$, double labeled with monoclonal c-myc antibody $(A, C)$ and polyclonal peripherin antibody $(B, D)$, show nearly perfect overlap of endogenous and transgene expression in DRG cells and enteric neurons, respectively. Similarly labeled sections of the cervical spinal cord $(E, F)$ show one of the few areas in periph/periph-myc animals in which peripherin-positive neurons, some motor neurons $(F)$, poorly express peripherin-myc fusion protein (arrowheads, E). Scale bar, $20 \mu \mathrm{m}$.

\section{Embryonic periph/periph-myc expression}

To determine whether peripherin-myc expression patterns when initially established were identical to those observed in the adult, periph/periph-myc mice were analyzed at early embryonic ages. Embryos were taken from lines in which adult transgene expression was closest to that of endogenous peripherin and expression patterns were compared to those of nontransgenic littermates.

Initial expression of periph/periph-myc was detected in the nervous system in rare scattered fibers in the neural tube and brainstem at E9 and in DRGs at E10, as is endogenous peripherin (Troy et al., 1990a). At E12 and E15, ages at which the endogenous peripherin gene and periph/lac $Z$ showed tremendous increases in PNS expression, periph/periph-myc transgene expression was neuron-specific throughout the PNS. Endogenous peripherin and peripherin-myc both were expressed in the motor neurons of the anterior horn, in autonomic nuclei, and in some regions of the brainstem. The localization of the transgene protein in the embryos, therefore, generally paralleled the 


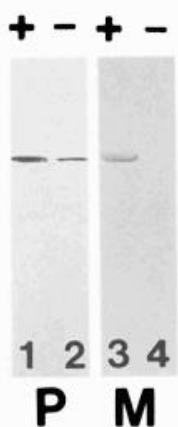

Figure 4. Myc antibody detects only peripherin-myc fusion protein, identical in relative molecular weight to endogenous peripherin, in per$\mathrm{iph}$ /periph-myc transgenic animals. Equivalent amounts of total protein derived from sciatic nerve preparations of periph/periph-myctransgenic (lanes 1 and 3) or nontransgenic (lanes 2 and 4 ) animals and reacted with peripherin antiserum $(P)$ or $m y c$ antibody $(M)$ indicate that peripherin-myc protein is the same molecular weight as that of endogenous peripherin (compare lanes 2 and 3 ) and that myc antibody reacts only with the peripherin-myc fusion protein (compare lanes 3 and 4).

expression patterns seen in adult tissues. Two exceptions to this observation were noted.

As seen for expression of the periph/lac $Z$ transgene, the per$\mathrm{iph}$ /periph-myc transgene also was expressed in the rostral heart as early as E8. This staining was most extensive at E10 (Fig.
$5 A$ ), and began to diminish by E12. Endogenous peripherin was found in the rostral heart (Fig. $5 B$ ) in a distribution identical to that seen for $\beta$-gal (Fig. $2 C$ ) and peripherin-myc (Fig. 5A). The second exception was that the transgene was expressed in all of the neurons of the DRG (Fig. $5 C, D$ ), as has been noted previously for the endogenous peripherin gene in the embryo (Troy et al., 1990a).

Thus, peripherin-myc expression paralleled that of the endogenous peripherin gene and, other than the exceptions noted, that seen in adult periph/periph-myc mice. In addition, as was noted in periph/periph-myc adults, expression of this transgene was not as variable as in the periph/lacZ mice, nor was ectopic expression observed in early development.

\section{Regulation of periph/lacZ and periph/periph-myc following axonal injury}

After nerve crush, peripherin immunoreactivity increases in ipsilateral, but not contralateral, anterior horn motor neurons (Troy et al., 1990b). In addition, more large-sized neurons of the DRG on the operated side are immunoreactive for peripherin than on the side contralateral to injury or in sham-operated animals (Oblinger et al., 1989; Wong and Oblinger, 1990). To define segments of the rat peripherin gene that are necessary to obtain its characteristic upregulation following injury to peripheral axons, the response of both transgenes to peripheral nerve injury was analyzed. The sciatic nerve was crushed uni-
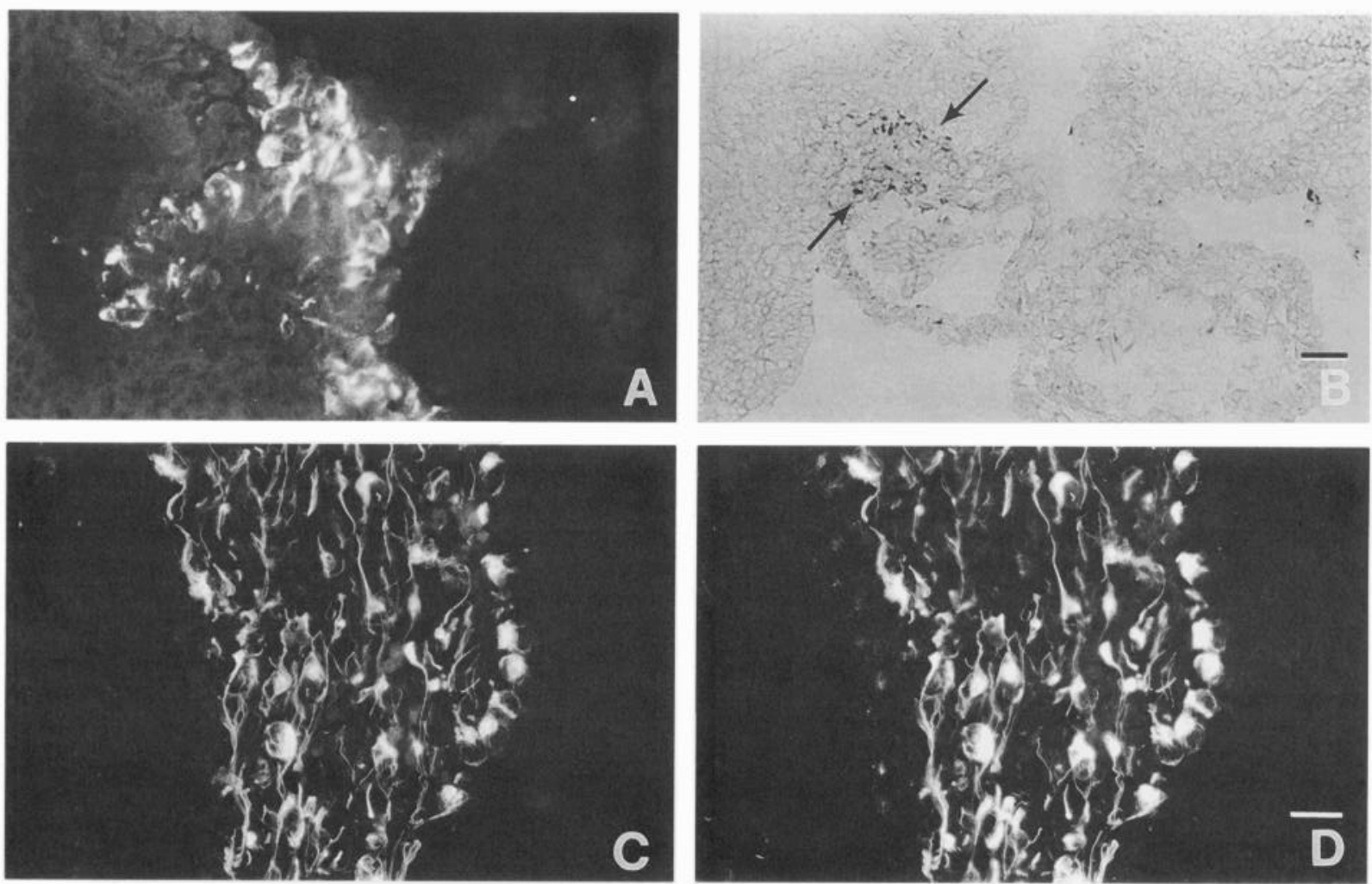

Figure 5. Periph/periph-myc expression overlaps that of endogenous peripherin during development. Sections of the cardiac region of an E9 embryo positive for the periph/periph-myc transgene unexpectedly showed expression of the peripherin-myc protein in the rostral heart region $(A)$. To determine whether endogenous peripherin was expressed in the same region, sections of a comparable region of a nontransgenic mouse were labeled with peripherin antibody. Indeed, the rostral heart contains peripherin (arrows, $B)$. Sections of the E12 DRG $(C, D)$ show that expression of periph/periph-myc $(C)$ correlates perfectly with that of the endogenous peripherin gene $(D)$ in all DRG sensory neurons during development. Scale bars: $B, 40 \mu \mathrm{m} ; D, 20 \mu \mathrm{m}$ for $A, C$, and $D$ 

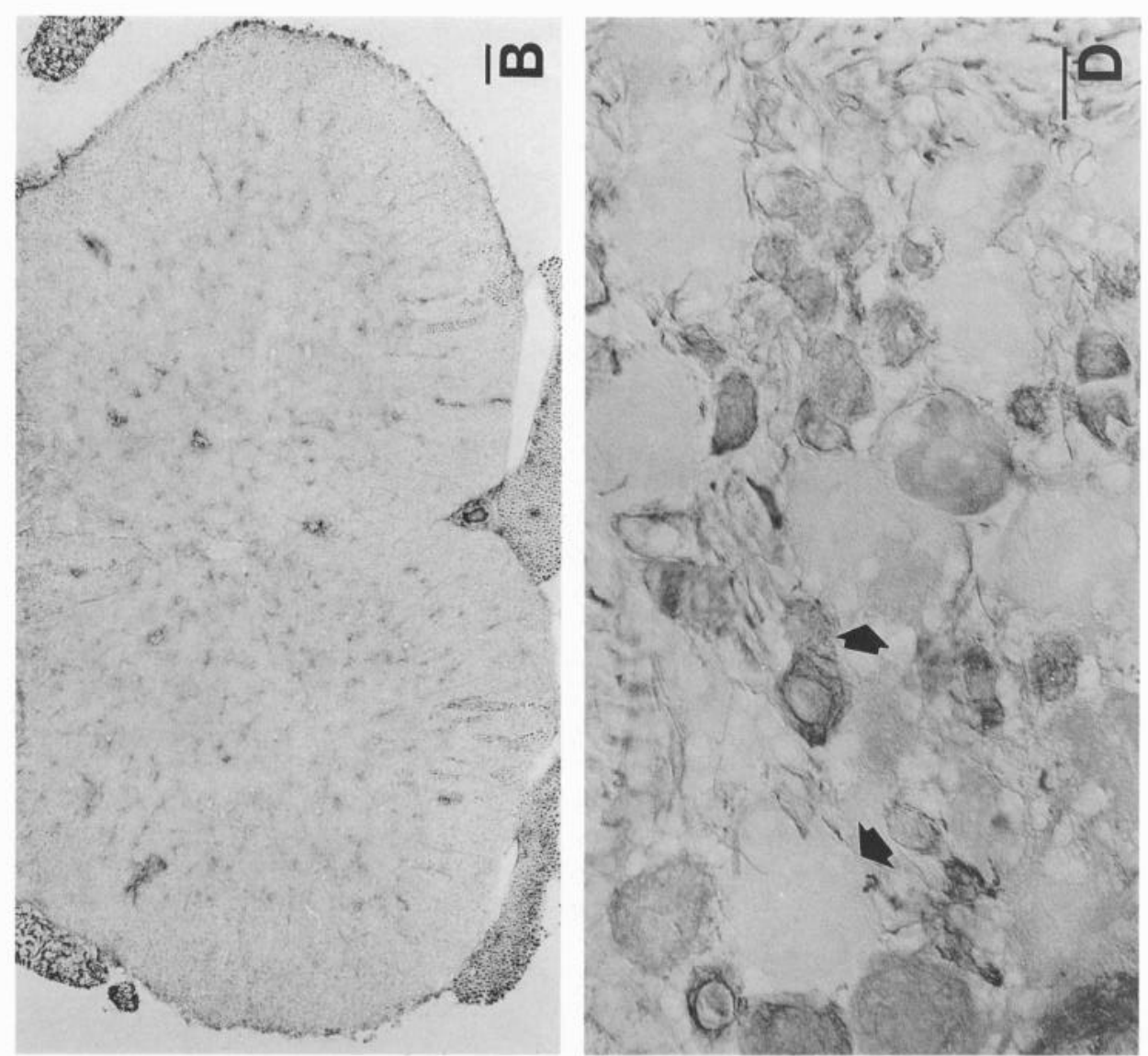

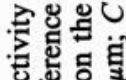

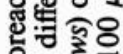

这里

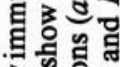

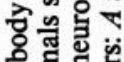

:

ㅇํ은

든

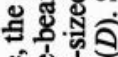

80

태

을.

记

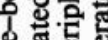

㣢

管

든

대용

므

응

总氮

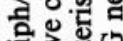

㝕然

트웡영

을

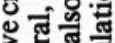

总
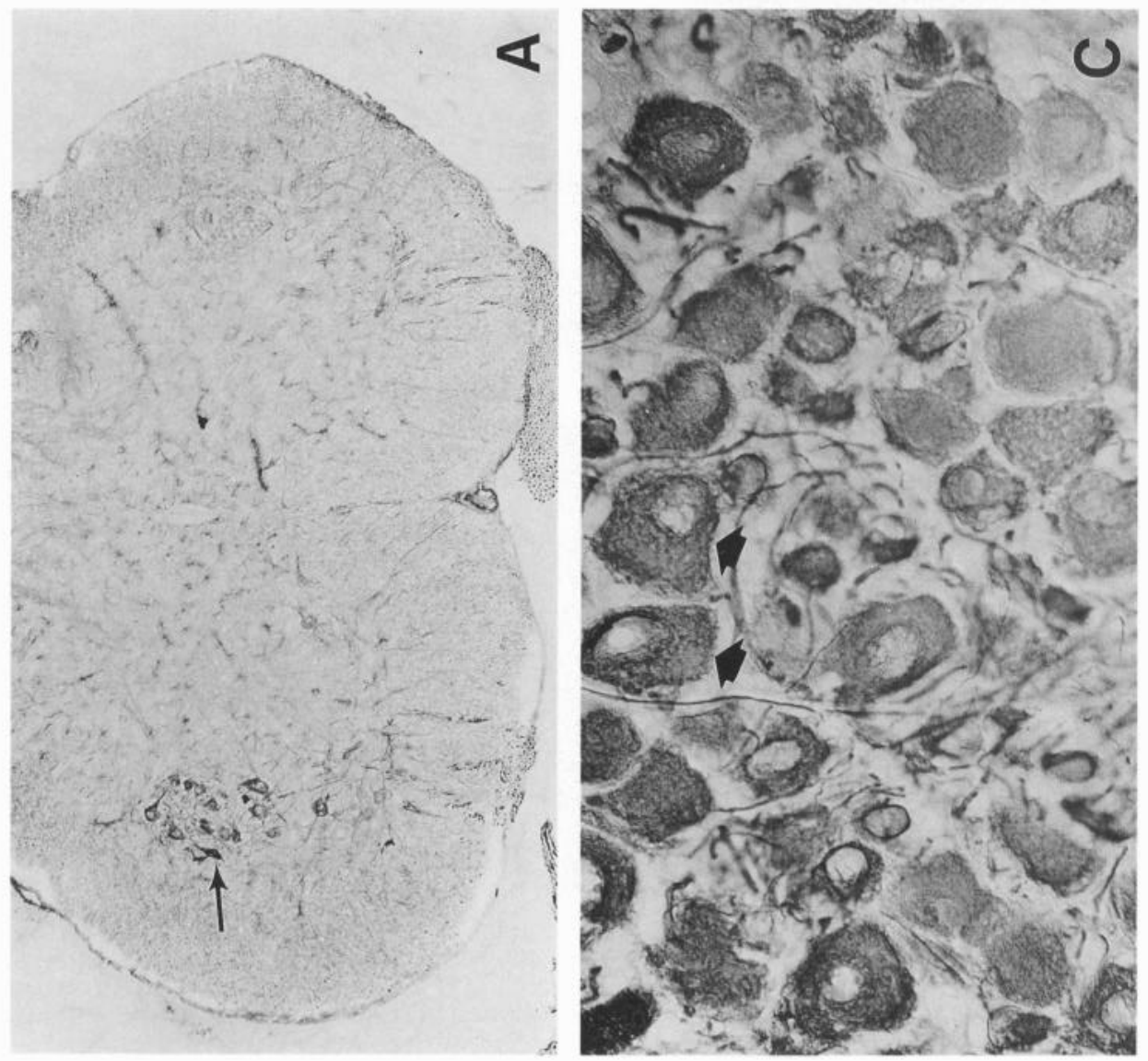

罟品

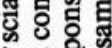

运运要

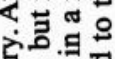

客和

을

웡

애의

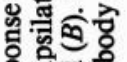

훙물

ज.

o

동의

이워

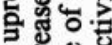

竞:

䟘

든

등.

今过

音

응응

믈

형형

현현

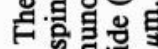

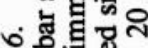

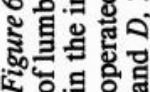


laterally in the right flank of groups of periph/periph-myc and periph/lac $Z$ transgenic mice and nontransgenic littermates. Additional controls included sham-operated animals of each group, in which the sciatic nerve was located but not crushed, and nonoperated animals. Ten days following the surgery, the mice were killed and the lumbar spinal cord and L4 and L5 DRGs from both operated and contralateral sides were processed for immunohistochemistry. Sections $(14 \mu \mathrm{m})$ were taken through the tissue, and adjacent sections were reacted with peripherin and $m y c$ antibody (for periph/periph-myc mice) or reacted with peripherin antiserum and stained with X-gal (for periph/lacZ mice). Tissue sections derived from each group of animals were processed at the same time under identical conditions.

Sections from periph/periph-myc mice showed an increase in the $m y c$ immunoreactivity of anterior horn motor neurons on the side ipsilateral, but not contralateral, to the nerve crush (Fig. $6 A$ ). Sham-operated transgenic littermates did not show any increase in immunoreactivity in anterior horn neurons in either location (Fig. 6B). There was also an increase in the number of $m y c$-immunoreactive large-sized DRG neurons on the side on which the nerve crush was performed (Fig. $6 C$ ) as compared to the same DRGs from sham-operated transgenic mice (Fig. $6 D$ ). There was no detectable change in $m y c$ immunoreactivity of neurons in DRGs contralateral to the nerve crush (not shown). Thus, genomic elements responsive to nerve injury were contained within a $9.8 \mathrm{~kb}$ segment containing the periph/periph$m y c$ transgene.

To determine whether 5 ' peripherin gene flanking sequences alone were sufficient for the response to axonal injury, nerve crush experiments werc performed on periph/lac $Z$ mice. As described earlier, the periph/lac $Z$ gene was not expressed in anterior horn motor neurons or large-sized DRG cells in adult mice; however, it remained to be determined whether nerve crush would activate periph/lac $Z$ expression in these cells. Ten days after nerve crush, no $\beta$-gal was detectable in either cell type. The nerve injury response also was tested in one line of periph/lac $Z$ animals that contained $\beta$-gal in embryonic, but not adult, motor neurons. Sections derived from this line of adult animals after nerve crush, however, also contained no detectable $\beta$-gal in motor neurons, nor was there an increase in the number of $\beta$-gal-stained DRG neurons as compared to sham-operated transgenic control animals. Therefore, the lac $Z$ transgene containing $5^{\prime}$ flanking sequences alone could not be activated, even by a nerve injury stimulus, in adult animals. These results imply that peripherin intragenic sequences are required for basal expression in these cell types in adult tissue and, therefore, also appear to be required for the injury response. This conclusion, however, must be substantiated by further experimentation.

\section{Discussion}

In the present study, we used transgenic mice to delimit peripherin gene sequences necessary for tissue-specific and developmental-specific expression and to define sequences necessary for the increased expression of peripherin after peripheral nerve injury. These studies showed that $5.8 \mathrm{~kb}$ of $5^{\prime}$ flanking peripherin gene sequences is sufficient to direct nervous system-specific expression of the transgene and correct temporal expression during development, but that intragenic sequences are required for complete cell type-specific expression. Strikingly, we observed upregulation of peripherin transgene expression following axonal injury; this response also may require intragenic sequences.

\section{Injury response elements}

Axonal injury induces a set of physical responses in peripheral neurons that are accompanied by changes in the expression of many proteins, including GAP43 (Skene and Willard, 1981), tubulin (Heacock and Agranoff, 1982), actin (Tetzlaff et al., 1988), microtubulc-associated protcins (Svensson and Aldskogius, 1992), neurofilament proteins (Hoffman and Lasek, 1980), and peripherin (Oblinger et al., 1989). The role of these proteins in the response to injury and subsequent regrowth of daughter axons has been inferred by the level of their expression as compared to preinjury levels and the time course of changes in their expression after injury. For example, the levels of type IV neural IF proteins decrease after injury, and do not return to preinjury levels until the newly growing axons are thought to reach their targets (Hoffman and Lasek, 1980; Hoffman et al., 1985, 1987; Wong and Oblinger, 1987). Based on these results, a role for type IV IF proteins in radial growth, rather than extension, of axons was suggested (Hoffman et al., 1985, 1987). In contrast, peripherin mRNA is significantly upregulated by axonal injury in rats and the mRNA levels remain higher than those of the preinjury state for $56 \mathrm{~d}$ following the nerve insult (Wong and Oblinger, 1990). These data implied a role for peripherin in the growth and regeneration of axons (Oblinger et al., 1989; Wong and Oblinger, 1990). The mechanism by which these changes occur is largely unknown, but it is likely to include transcriptional control. Clearly, a full understanding of regeneration will require a description of the role played by each protein with altered expression as well as analysis of the mechanisms that mediate transcriptional responses to nerve injury.

In the present studies, we sought to analyze how injury alters peripherin gene expression by determining whether injury-responsive elements were contained within peripherin transgenes. The periph/periph-myc transgene was expressed in the largesized sensory cells of the DRG and the anterior horn motor neurons, and its expression increased after nerve crush, mirroring expression of the endogenous peripherin gene. These data indicated that injury-responsive sequences resided within a 9.8 kb genomic segment containing the peripherin gene. We then wished to know whether the flanking sequences alone were sufficient for the injury response. The transgene containing only peripherin gene 5 ' flanking sequences, periph/lac $Z$, however, was not expressed in the large-sized DRG cells and anterior horn motor neurons in adult tissue, the very neurons in which peripheral injury responses are typically studied. These data indicated that scquences within the body of the peripherin gene are necessary for basal expression in cells that show an injury response. It is possible that properties of the lac $Z$ reporter gene may have interfered with expression of the transgene (Brinster et al., 1988; Choi et al., 1991; Palmiter et al., 1991), particularly in injury-responsive cells; however, another study that used the identical lacZ gene showed that the reporter gene did not interfere with the ability of 5 ' hanking sequences alone to direct cell type-specific expression of the $E n-2$ gene in both embryonic and adult mice (Logan et al., 1993). The increase in endogenous peripherin gene and periph/periph-myc transgene expression normally seen in these cells after nerve injury, therefore, could be mediated by the same or distinct sequences required for cell type-specific expression. Our results indicate that these sequences lie within the peripherin gene and/or $5.8 \mathrm{~kb}$ of $5^{\prime}$ flanking region.

Since the periph/periph-myc transgene responded to injury, 
the most direct way of identifying injury-responsive elements will be to perform further nerve crush experiments in animals bearing transgenes from which potential injury-responsive elements of the periph/periph-myc transgene are deleted. To identify candidate sequences that might play a role in the injury response, we scanned the periph/periph-myc transgene sequence for elements that might be common to another set of genes that are activated early and in many kinds of neural stress and injury, the heat-shock protein genes (Tytell and Barbe, 1987; New et al., 1989; reviewed in Brown 1990). Indeed, two consensus heatshock elements (Amin et al., 1988) were found in the $5^{\prime}$ flanking sequence of the peripherin gene (data not shown). Sequence analysis of the human peripherin gene and comparison with rodent peripherin genes (J. Foley, C. A. Ley, and L. M. Parysek, unpublished observations) indicates that these elements are conserved among rat, mouse, and human peripherin genes. Further studies will determine whether deletion of the heat-shock elements abolishes the injury response of the peripherin gene and whether heat-shock transcription factors bind to the candidate heat-shock elements.

\section{Expression of peripherin in the heart}

In the present study, both the periph/lac $Z$ and periph/periph$m y c$ transgenes were expressed in the cardiac region of the embryo. These findings were unexpected because peripherin had not been detected previously in the heart region of developing embryos, or in adult heart. Since peripherin has been found in many cells derived from the neural crest, it is possible that, in the heart, peripherin is expressed in cells derived from the cardiac neural crest that form part of the aortic arch, aorticopulmonary septum, truncal folds, and cardiac parasympathetic innervation (summarized in Kirby and Waldo, 1990). Consistent with this idea, we found that $\beta$-gal staining, peripherin- $m y c$, and endogenous peripherin expression were localized transiently to the rostral portion of the heart, where the cardiac outflow tract and aortic arches are found. Further study is needed to trace the origin of the cells expressing peripherin in the heart and the importance of this expression for heart development.

\section{Conclusion}

The characterization of gene sequences that mediate transcriptional responses to peripheral nerve injury is essential to the identification of trans-acting factors that regulate regeneration. We have established a system for such studies by defining a peripherin transgene that is expressed in a cell type-specific manner and responds to nerve injury. These studies provide the basis for fine localization of these regulatory sequences and for studies on their role in developmental and regenerative processes.

\section{References}

Amin J, Ananthan J, Voellmy R (1988) Key features of heat shock regulatory elements. Mol Cell Biol 8:3761-3769.

Basi GS, Jacobson RD, Virag I, Schilling J, Skene JHP (1987) Primary structure and transcriptional regulation of GAP-43, a protein associated with nerve growth. Cell 49:785-791.

Brinster RL, Allen JM, Behringer RR, Gelinas RE, Palmiter RD (1988) Introns increase transcriptional efficiency in transgenic mice. Proc Natl Acad Sci USA 85:836-840.

Brody BA, Ley CA, Parysek LM (1989) Selective distribution of the $57 \mathrm{kDa}$ neural intermediate filament protein in the rat CNS. J Neurosci 9:2391-2401.
Brown IR (1990) Induction of heat shock (stress) genes in the mammalian brain by hyperthermia and other traumatic events: a current perspective. J Neurosci Res 27:247-255.

Chen WY, Wight DC, Mehta BV, Wagner TE, Kopchick JJ (1991) Glycine 119 of bovine growth hormone is critical for growth-promoting activity. Mol Endocrinol 5:1845-1852.

Choi T, Huang M, Gorman C, Jaenisch R (1991) A generic intron increases gene expression in transgenic mice. Mol Cell Biol 11:3070 3074.

Daniloff JK, Levi G, Grumet M, Rieger F, Edelman GM (1986) Altered expression of neuronal cell adhesion molecules induced by nerve injury and repair. J Cell Biol 103:929-945.

Ernfors P, Henschen A, Olson L, Persson H (1989) Expression of ncrve growth factor receptor mRNA is developmentally regulated and increased after axotomy in rat spinal cord motoneurons. Neuron 2:1605-1613

Escurat M, Djabali K, Gumpel M, Gros F, Portier M-M (1990) Differential expression of two neuronal intermediate-filament proteins, peripherin and the low-molecular-mass neurofilament protein (NFL), during the development of the rat. J Neurosci 10:764-784.

Evan GI, Lewis GK, Ramsay G, Bishop M (1985) Isolation of monoclonal antibodies specific for human c-myc proto-oncogene product. Mol Cell Biol 5:3610-3616.

Foley J, Cohn SL, Salwen HR, Chagnovich D, Cowan J, Mason KL, Parysek LM (1991) Differential expression of $\mathrm{N}$-myc in phenotypically distinct subclones of a human neuroblastoma cell line. Cancer Res 51:6338-6345.

Goldstcin ME, Weiss SR, Lazzarini RA, Shneidman PS, Lees JF, Schlaepfer WW (1988) mRNA levels of all three neurofilament proteins decline following nerve transection. Mol Brain Res 3:287292.

Gorham JD, Baker H, Kegler D, Ziff EB (1990) The expression of the neuronal intermediate filament protein peripherin in the rat embryo. Dev Brain Res 57:235-248.

Grafstein B (1975) The nerve cell body response to axotomy. Exp Neurol 48:32-51.

Hanley T, Merlie JP (1991) Transgene detection in unpurified mouse tail DNA by polymerase chain reaction. Biotechniques 10:56.

Heacock AM, Agranoff BW (1982) Protein synthesis and transport in the regenerating goldfish visual system. Neurochem Res 7:771-788.

Heumann R, Lindholm D, Bandtlow C, Meyer M, Radeke MJ, Misko TP, Shooter E, Thoencn H (1987a) Differential regulation of mRNA encoding nerve growth factor and its receptor in rat sciatic nerve during development, degeneration, and regeneration: role of macrophages. Proc Natl Acad Sci USA 84:8735-8739.

Heumann R, Korsching S, Bandtlow C, Thoenen H (1987b) Changes of nerve growth factor synthesis in nonneuronal cells in response to sciatic nerve transection. J Cell Biol 104:1623-1631.

Hoffman PN, Cleveland DW (1988) Neurofilament and tubulin expression recapitulates the developmental program during axonal regeneration: induction of a specific beta tubulin isotype. Proc Natl Acad Sci USA 85:4530-4533.

Hoffman PN, Lasek RJ (1980) Axonal transport of the cytoskeleton in regenerating motor neurons: constancy and change. Brain Res 202: 317-333.

Hoffman PN, Thompson GW, Griffin JW, Price DL (1985) Changes in neurofilament transport coincide temporally with alterations in the caliber of axons in regenerating motor fibers. J Cell Biol 101:13321340.

Hoffman PN, Cleveland DW, Griffin JW, Landes PW, Cowan NJ, Price DL (1987) Neurofilament gene expression: a major determinant of axonal caliber. Proc Natl Acad Sci USA 84:3472-3476.

Hogan B, Costantini F, Lacy E (1986) Manipulating the mouse embryo: a laboratory manual. Cold Spring Harbor, NY: Cold Spring Harbor Laboratory.

Kirby ML, Waldo KL (1990) Role of neural crest in congenital heart disease. Circulation 82:332-340.

Kress C, Vogels R, De Graaff W, Bonnerot C, Meijlink F, Nicolas J-F, Deschamps J (1990) Hox-2.3 upstream sequences mediate lac $Z$ cxpression in intermediate mesoderm derivatives of transgenic mice. Development 109:775-786.

Leonard DGB, Ziff EB, Greene LA (1987) Identification and characterization of mRNAs regulated by nerve growth factor in $\mathrm{PCl} 2$ cells. Mol Cell Biol 7:3156-3167.

Leonard DGB, Gorham JD, Cole P, Greene LA, Ziff EB (1988) A 
nerve growth factor-regulated messenger RNA encodes a new intermediate filament protein. J Cell Biol 106:181-193.

Logan C, Khoo WK, Cado D, Joyner AL (1993) Two enhancer regions in the mouse $E n-2$ locus direct expression to the mid/hindbrain region and mandibular myoblasts. Development 117:905-916.

New GA, Hendrickson BR, Jones KJ (1989) Induction of heat shock protein $70 \mathrm{mRNA}$ in adult hamster facial nuclear groups following axotomy of the facial nerve. Metab Brain Dis 4:273-279.

Oblinger MM, Wong J, Parysek LM (1989) Axotomy-induced changes in the expression of a type III neuronal intermediate filament gene. J Neurosci 9:3766-3775.

Palmiter RD, Sandgren EP, Avarbock MR, Allen DD, Brinster RL (1991) Heterologous introns can enhance expression of transgenes in mice. Proc Natl Acad Sci USA 88:478-482.

Parysek LM, Goldman RD (1987) Characterization of intermediate filaments in PCl 2 cells. J Neurosci 7:781-791.

Parysek LM, Goldman RD (1988) Distribution of a novel $57 \mathrm{kDa}$ intermediate filament (IF) protein in the nervous system. J Neurosci 8:555-563.

Parysek LM, Chisholm RL, Ley CA, Goldman RD (1988) A type III intermediate filament gene is expressed in mature neurons. Neuron $1: 395-401$.

Parysek LM, McReynolds MA, Goldman RD, Ley CA (1991) Some neural intermediate filaments contain both peripherin and the neurofilament proteins. J Neurosci Res 30:80-91.

Portier M-M, Croizat B, Gros F (1982) A sequence of changes in cytoskeletal components during neuroblastoma differentiation. FEBS Lett 146:283-288.

Portier M-M, de Nechaud B, Gros F (1984) Peripherin, a new member of the intermediate filament protein family. Dev Neurosci 6:335-344.

Sambrook J, Fritsch EF, Maniatis T (1989) Molecular cloning: a laboratory manual. Cold Spring Harbor, NY: Cold Spring Harbor Laboratory.

Sharpe CR, Pluck A, Gurdon JB (1989) XIF3, a Xenopus peripherin gene, requires an inductive signal for enhanced expression in anterior neural tissue. Development 107:701-714.
Skene JHP (1989) Axonal growth-associated proteins. Annu Rev Neurosci $12: 127-156$.

Skene JHP, Willard M (1981) Axonally transported proteins associated with axon growth in rabbit central and peripheral nervous systems. J Cell Biol 89:96-103.

Svensson M, Aldskogius H (1992) The effect of axon injury on microtubule-associated proteins MAP2, 3 and 5 in the hypoglossal nucleus of the adult rat. J Neurocytol 21:222-231.

Tetzlaff W, Bisby MA, Kreutzberg GW (1988) Changes in cytoskeletal proteins in the rat facial nucleus following axotomy. J Neurosci 8:31813189.

Thompson MA, Ziff EB (1989) Structure of the gene encoding peripherin, an NGF-regulated neuronal-specific type III intermediate filament protein. Neuron 2:1043-1053.

Towbin H, Staehelin T, Gordon J (1979) Electrophoretic transfer of proteins from polyacrylamide gels to nitrocellulose sheets: procedure and some applications. Proc Natl Acad Sci USA 76:4350-4354.

Troy CM, Brown K, Greene LA, Shelanski ML (1990a) Ontogeny of the neuronal intermediate filament protein, peripherin, in the mouse embryo. Neuroscience 36:217-237.

Troy CM, Muma NA, Greene LA, Price DL, Shelanski M (1990b) Regulation of peripherin and neurofilament expression in regenerating rat motor neurons. Brain Res 529:232-238.

Tytell M, Barbe MF (1987) Synthesis and axonal transport of heat shock proteins. In: Axonal transport (Smith RS, Bisby MA, eds), pp 473-492. New York: Liss.

Varon S (1977) Neural growth and regeneration: a cellular perspective. Exp Neurol 54:1-6.

Watson WE (1974) Cellular responses to axotomy and to related procedures. Br Med Bull 30:112-115.

Wong J, Oblinger MM (1987) Changes in neurofilament gene expression occur after axotomy of dorsal root ganglion neurons: an in situ hybridization study. Metab Brain Dis 2:291-303.

Wong J, Oblinger MM (1990) Differential regulation of peripherin and neurofilament gene expression in regenerating rat DRG neurons. J Neurosci Res 27:332-341. 